\title{
Rare-metal pegmatites of Renli deposit, SE China: Their formation in realtionship to Mufushan composite granitoid batholith
}

PENG Li ${ }^{1 *}$, JiANKANG $\mathrm{Li}^{1}$, ZHENYU CHEN ${ }^{1}$, XIANG LiU ${ }^{2}$, ZHEN WANG ${ }^{1}$, ZHIBIAO HUANG ${ }^{2}$, FANGCHUN ZHOU ${ }^{2}$

${ }^{1}$ Institute of Mineral Resources, Chinese Academy of Geological Sciences, Beijing 100037, China

(*correspondence: lipeng031111@163.com)

${ }^{2}$ Hunan Nuclear Geology, Changsha 410011, China

The giant Renli rare-metal deposit in northern Hunan province of China is located at the south margin of the Mufushan batholith. The southern part of the composite granitoid batholith is composed of at least one stage of biotite monzogranite (G1) and three stages of two-mica monzogranites (G2, G3 and G4). From NE to SW, more than 140 major pegmatite dykes exposed in the deposit can be approximately divided into four zones from near to far from the Mufushan batholith: microcline pegmatite zone (P1); (garnet-bearing) microcline-albite pegmatite zone (P2); albite pegmatite zone (P3); and albite-spodumene pegmatite zone (P4). Correspondingly, with the distance from the batholith, the dominant alikaline elements change from $\mathrm{K}$ to $(\mathrm{K}+\mathrm{Na})$ to $\mathrm{Na}$ and then to $(\mathrm{Na}+\mathrm{Li})$, the scales of the dykes decrease, and the rare-metal mineralization type changes from single to complex $(\mathrm{Be} \rightarrow \mathrm{Be}+\mathrm{Nb}+\mathrm{Ta} \rightarrow \mathrm{Be}+\mathrm{Nb}+\mathrm{Ta}+\mathrm{Li})^{[1,2]}$.

Chemical analyses of 14 primary muscovite samples from the four stages Mufushan granites, 3 primary muscovite samples from the buried granite in depth (biotite monzogranite; G5), and 101 primary muscovite samples from the four types of pegematites show continuous evolution trend of magma differentiation. From biotite monzogranite to two-mica monzogranite, and then to the four types pegmatites (from P1 to P4), the average contents of $\mathrm{Li}, \mathrm{Rb}, \mathrm{Cs}$, Ta and F in muscovites increase gradually and the $\mathrm{K} / \mathrm{Rb}$ and $\mathrm{K} / \mathrm{Cs}$ ratios decrease, reflecting the increasing differentiation degree of magma and the mineralization potential of the pegmatite from the margin to the outmost zone of the batholith. From granite to pegmatite, the continuous differentiation trend of magma and gradually enrichments of rare metal elements indicate that Mufushan batholith could provid the material source for the rare metal pegmatites. The G4 with the highest differentiation degree in granites, whose average $\mathrm{K} / \mathrm{Rb}$ ratio is close to pegmatite, is considerd to have close relationship with the Renli pegmatites.

[1] Li et al. (2019) Ore Geol Rev 115, 103187. [2] Li et al. (2020) Ore Geol Rev 116, 103237. 